\title{
MEDICAL EVACUATION OF PATIENTS COVID-19
}

Baranova NN1,2, Akin'shin AV, Goncharov SF, Meshkov MA³ , Zelentsov KM, Pys'mennij VP'1

${ }^{1}$ Russian Center for Disaster Medicine "Zashchita" of FMBA of Russia, Moscow, Russia

${ }^{2}$ Russian Medical Academy of Continuous Professional Education of the Russian Ministry of Healthcare, Moscow, Russia

${ }^{3}$ Negovsky Research Institute of General Reanimatology, Moscow, Russia

\begin{abstract}
The aim of this article was to summarize the experience of the National Center for Disaster Medicine "Zashchita" in organizing and performing medical evacuations (including those by air) of patients with COVID-19. Materials and methods used in the study included legal, normative and guidance documents, emergency call forms, methods for preparing for and performing medical transport of patients with COVID-19, EMS safety guidelines. The article lists basic normative documents regulating medical evacuation of patients with infections, including COVID-19, and describes the missions carried out by Zashchita and their outcomes. So fat, the Center has successfully completed 555 medical evacuations, including 64 aeromedical missions. Biosafety of EMS teams involved in medical evacuations was ensured following the existing safety guidelines. For long journeys over $1 \mathrm{~h}$, PPE should be donned upon arrival at the scene before leaving the EMS vehicle. Using patient isolation transport units is mandatory during medical evacuations of COVID-19 patients by air. Prior to starting a mass medical evacuation of patients with COVID-19, their number and condition should be assessed to determine the priority sequence for evacuation and the required oxygen supply.
\end{abstract}

Keywords: COVID-19, coronavirus infection, PPE, medical evacuation, biosafety, aeromedical mission, patient isolation transport unit

Received: 26.06.2020 Accepted: 29.07.2020 Published online: 10.08.2020

DOI: $10.47183 /$ mes.2020.007

\section{МЕДИЦИНСКАЯ ЭВАКУАЦИЯ БОЛЬНЫХ COVID-19}

Н. Н. Баранова ${ }^{1,2}$, А. В. Акиньшин, С. Ф. Гончаров, М. А. Мешков ${ }^{3}$, К. М. Зеленцов, В. П. Письменный

1 ФГБУ «Всероссийский центр медицины катастроф «Защита» ФМБА России, Москва, Россия

2 ФГБОУ ДПО «Российская медицинская академия непрерывного профессионального образования» Минздрава России, Москва; Россия

${ }^{3}$ НИИ общей реаниматологии им. В.А. Неговского Федерального научно-клинического центра реаниматологии и реабилитологии, Москва, Россия

\begin{abstract}
Цель исследования - обобщение опыта специалистов ВЦМК «Защита» по организации и проведению медицинской эвакуации больных СОVID-19 в том числе авиационным транспортом. Материал и методы исследования: нормативные, методические документы, карты вызовов, методики подготовки и проведения медицинской эвакуации больных COVID-19, обеспечения инфекционной безопасности медицинской бригады, санитарного транспорта. Рассмотрены основные нормативные документы, регламентирующие организацию и проведение медицинской эвакуации больных инфекционного просиля, в том числе с новой короновирусной инфекцией COVID-19. Представлены основные результаты деятельности специалистов Всероссийского центра медицины катастроф "Защита" ФМБА России по проведению медицинской эвакуации больных COVID-19. Bсего выполнено 555 эвакуаций, в том числе 64 авиационным транспортом. Обеспечение инфекционной безопасности специалистов медицинских бригад выполнялось в соответствии с действующими нормативными документами. Их применение было достаточным для защиты бригады. При существенном увеличении времени доезда до инфекционного больного (1 час и более) СИЗ целесообразно одевать по прибытии на место, в санитарном транспорте. Применение транспортировочного изолирующего бокса при проведении санитарно-авиационной эвакуации обязательно для больных COVID-19. Организации массовой медицинской эвакуации больных COVID-19 следует начинать с предварительной оценки их количества и тяжести состояния, на основании которых определяется состав бригад СМП, очередность транспортировки, объем неснижаемого запаса кислорода в санитарном транспорте. Приведены примеры из практики организации и проведения санитарно-авиационных медицинских эвакуаций больных COVID-19.
\end{abstract}

Ключевые слова: средства индивидуальной защиты, COVID-19, коронавирусная инфекция, медицинская эвакуация, инфекционная безопасность, санитарно-авиационная эвакуация, транспортировочный изолирующий бокс

Статья получена: 26.06.2020 Статья принята к печати: 29.07.2020 Опубликована онлайн: 10.08.2020

DOI: $10.47183 /$ mes.2020.007

Prompt transport to a receiving facility is an essential part of delivering specialized or hi-tech medical care to patients infected with the novel coronavirus infection (COVID-19). In Russia, medical evacuation and transport of patients, including those with high-consequence infectious disease, are regulated by Order 69n of the Russian Ministry of Healthcare and Social Development (dated 01/31/2012) and the Chief Medical Officer's recommendations [1, 2]. As more and more people contracted the disease, a need arose for clarifying the procedure of medical evacuation/transportation and improving EMS personnel safety. This spurred an upadte (ver.7) of the Interim recommendations providing detailed information on the stages of medical transportation/evacuation developed and revised by the experts of the National Center for Disaster Medicine "Zashchita" of FMBA ( NCDM Zashchita), Russia, based on the experience accumulated to date [3].

There are a few important normative documents clarifying and amending currently existing guidelines on medical evacuation/transport that were developed to regulate the evacuation procedure in patients suspected, probable or confirmed to have COVID-19. The EMS patient transport protocol for suspected/confirmed COVID-19 cases is provided in FMBA Order 112 dated 04/18/2020 and Order 126 dated 04/24/2020 [4, 5]. The protocol requires a responding EMS team cooperating with an infectious disease specialist to determine the number and order of evacuations for patients with confirmed or suspected COVID-19 and coordinate the transportation route. FMBA Order 112 dated 04/18/2020 describes the PPE donning and doffing procedure and requires the EMS personnel to put on their protective gowns under the supervision of the EMS team leader upon arriving at the scene prior to entering the patient's home or isolation area. The EMS personnel involved in medical evacuation are not required to self-isolate for 14 days as before but instead are closely monitored for the entire length of the COVID-19 incubation period.

NCDM Zashchita has developed a guidance on the medical evacuation and transportation of patients with infectious diseases, including high-consequence infectious diseases. The 
guidance is open for criticism and improvements at the website of NCDM Zashchita [6].

The letter of Rospotrebnadzor[1] (The Russian Federal Service for Surveillance on Consumer Rights Protection and Human Well-being ) has authorized the air medical services (AMS) of NCDM Zashchita involved in the medical evacuation of patients and disaster victims to proceed with the assigned tasks without having to self-isolate for 14 days after the mission given that the medical personnel strictly complies with all biosafety rules. This decision has significantly improved the efficacy of medical evacuation and transportation.

Our search for the international literature on the medical evacuation of COVID-19 patients did not yield any results. So, the aim of this study was to summarize the experience of the Center for Emergency Air Evacuation (CEAE) and the Multipurpose Field Hospital (MFH) of NCDM Zashchita in organizing and performing medical evacuations (including those by air) of patients with COVID-19.

Materials and methods used in the study include legal, normative and guidance documents, emergency call forms, methods for preparing for and performing medical transport of patients with COVID-19, EMS safety guidelines.

\section{Study results and analysis}

Medical evacuation of patients with COVID-19 was performed by the medical personnel of NCDM Zashchita.

The first aeromedical evacuation mission of COVID-19 patients ( 3 confirmed and 5 suspected cases) was conducted by CEAE personnel on February 21-24, 2020. The patients were transferred from Tokyo, Japan, to a receiving facility in Kazan on board of a specialized aircraft. Of 8 patients, 5 had a history of face-to-face contacts with infected individuals and 3 were positive for COVID-19. Visual examination of the patients, change of respirators and non-contact temperature assessment were performed in a vehicle prior to boarding the plane. On examination, all patients had normal temperature readings and no health complaints. During the flight, which lasted for $18 \mathrm{~h}$ including refueling stops, the patients' condition was closely monitored. At refueling stops, the patients and the medical crew stayed on board. The EMS crew consisted of an anesthesiologist and a paramedic. The EMS crew were wearing PPE, including Tychem $2000 \mathrm{C}$ hooded coveralls (DuPont), FFP3-standard 6800 full respirator masks (3M), high shoe covers with straps, surgical gloves, and QUARTZ-1M protective gowns [7].

The EMS team were wearing PPE over medical scrub pants and a V-neck top. The escorting Rospotrebnadzor and EMERCOM personnel and the aircraft crew members were wearing similar PPE. The patients were wearing FFP3 respirators without exhalation valves. Upon landing, the patients were transported to the specialized receiving facility; after the flight, the aircraft was cleaned and disinfected; the aircraft personnel also underwent the decontamination procedure [8].

Most aeromedical missions tasked by the Russian government were conducted using medically equipped aircrafts.
At the time of the performed evacuations, $40.0 \%$ of the patients were positive for COVID-19; other patients, including those with a past history of contacts with infected individuals, did not take a COVID-19 test or their test results were unavailable. However, all patients had clinical signs of pneumonia, including a high respiration rate, labored breathing, fever, and some other symptoms suspicious of COVID-19.

Indications and contraindications to air transport were determined based on the severity of the patients' condition. Among direct contraindications were refractory bleeding, hemodynamic instability, pneumothorax, pneumocephalus, and other conditions that could not be corrected or stabilized on board of an aircraft or an EMS car. None of the patients had contraindications to transport.

During short-term ( $>1 \mathrm{~h}$ ) evacuation missions, patients were continuously monitored for their heart rate, oxygen saturation and body temperature. Blood pressure was measured once every 15 minutes. Other parameters were measured depending on a patient's condition. In most cases, there was no need for pathogenic therapy, but all patients received oxygen. During long-term missions (including air evacuations), the amount of diagnostic and therapeutic interventions was determined by a patient's condition.

In all cases, after CEAE received a request for medical evacuation, information about the time of the diagnosis and the involved specialist, severity of the condition and COVID-19 test results was further clarified.

According to the interim guidance (ver.7) on the prophylaxis, diagnosis and treatment of the novel coronavirus infection released by the Russian Ministry of Healthcare, an EMS team involved in medical evacuation must include 1 physician, 1 paramedic and 1 nurse [3]. On our missions, there was no nurse, whose responsibilities were distributed between the 2 remaining members of the team.

Protecting EMS personnel against the infection is an important priority. The personnel involved in the transport of patients suspected to have COVID-19 must wear class 4B disposable protective clothing and FFP2 or higher-class respirators.

In our experience, donning all PPE prior to leaving the EMS station is not well-reasoned. Considering conflicting recommendations on PPE donning (before leaving the EMS station or at the scene) provided in the normative documents, we follow the guidelines provided by FMBA Order 112 dated 04/18/2020. EMS personnel engaged in patient transportation in the city of Moscow put on their protective gowns before leaving the EMS station; eye protection and respirators are put on upon arrival at the scene before leaving the EMS vehicle. For emergencies outside Moscow or longer journeys (>1 h), coveralls, eye protection and respirators are donned upon arriving at the scene before leaving the car.

EMS vehicle drivers also wear protective gowns, respirators and medical gloves. Goggles are not used because they might affect the driver's reaction to an unexpected situation on the road. A patient compartment is separated from the driver's cabin by a polyethylene screen. During medical evacuations, the EMS team stays in the patient compartment and does not have any physical contact with the driver.

Table 1. Number of patients with COVID-19 evacuated by the Center for Emergency Air Evacuation and the Multipurpose Field Hospital of NCDM Zashchita between February 23, 2020 and June 20, 2020

\begin{tabular}{|c|c|c|c|c|c|}
\hline \multirow{2}{*}{ Patients } & \multirow{2}{*}{$\begin{array}{c}\text { All types of } \\
\text { transport }\end{array}$} & Total & In Russia & From abroad & \multicolumn{2}{|c|}{ EMS vehicles } \\
\cline { 3 - 5 } & & 555 & 63 & 52 & 11 \\
\hline $\begin{array}{c}\text { With confirmed or suspected } \\
\text { COVID-19 }\end{array}$ & 592 \\
\hline
\end{tabular}


During transport, the air in the vehicle is decontaminated by a bactericidal UV air recirculatory. Traces of biological materials in the vehicle are decontaminated using liquid disinfectants, collected into containers and disposed of as class B medical waste. Inside the vehicle, PPE and shoes are decontaminated with disinfectants.

NCDM Zashchita has developed and continues to implement the following protocol for aircraft disinfection:

- Once the patient is transferred to a receiving facility, all internal surfaces of the EMS vehicle, door handles and medical equipment are decontaminated with a disinfectant; PPE;

- EMS personnel returns to the headquarters still wearing

- At the headquarters, the vehicle, PPE and shoes are additionally decontaminated with disinfectants in a special decontamination area; the patient compartment of the vehicle is irradiated using an UV air recirculator. PPE are treated with a disinfectant (exposure time is controlled) and then are disposed of as class B medical waste;

- A record of the decontamination procedure is made in the log book, specifying the disinfectant used, exposure time and time for air decontamination [7].

Medical supplies inventory is restocked after the EMS team returns to the vehicle. This reduces the risk of accidental contamination of the headquarters building. Documentation, including emergency call forms, is decontaminated in a dry-air sterilizer.

Patient isolation transport units (PITU) are mainly used during aeromedical missions because:

- decontamination and setup of PITU for the next patient is a time- and labor-intense procedure, meaning they cannot be used in a series of emergency transportations;

- total decontamination of the entire aircraft with an infected patient on board transported without PITU is impossible.

A PITU envelope can be positively or negatively pressurized as per its manufacturer's protocol. Based on our experience of transporting COVID-19 patients, there are a few downsides to maintaining negative pressure inside PITU. First, despite the sufficient number of filters, the PITU envelope "shrinks", making it harder to perform medical manipulations and inciting anxiety and psychomotor agitation in the patient because of small confined space and "closing" capsule walls. During all aeromedical missions performed by Zashchita, mild positive pressure was maintained inside PITU. The inlet pump was not operated at full capacity, which allowed the battery to hold a charge for 1.5-2 more hours.

While preparing for a medical evacuation, we followed the minimum weight - maximum functionality rule. Therefore, we did not consider using portable hyperbaric chambers as an alternative to PITU. However, we believe that in the future it will be possible to transport infectious patients in intensive and isolated care units based on the Afalina module developed by Lomonosov MSU [8].

Below, we describe the medical evacuation of as severely ill COVID-19 patient inside a PITU on board of a specialized aircraft.

A patient with suspected COVID-19 progressed to severe bilateral multisegmental pneumonia, as suggested by a CT scan, was transferred on board of an $\mathrm{AN}-148$ aircraft from Grozny to Moscow on May 22-23, 2020; the patient was accompanied by the medical personnel from NCDM Zashchita. To ensure medical personnel and cabin crew safety and prevent contamination of aircraft surfaces and the ventilation system, the patient was placed in a PITU (emergency bag BIOBAG EBV-30/40). Upon arriving at Grozny airport, the EMS team donned their PPE and were taken to the hospital by an ambulance vehicle. At the hospital, the EMS team evaluated the patient's condition and did the paperwork. The patient was placed in an emergency bag; cables and sensors for vital signs monitoring (ECG, $\mathrm{SpO}_{2}$, blood pressure) were passed through the side ports. In order to compensate for respiratory failure, oxygen was delivered to the patient via a Venturi mask. Negative pressure was created and maintained in PITU further on so as to achieve the highest level of biological safety (BSL-4). Before loading the patient into an EMS vehicle, the EMS crew, PITU and the equipment (an electrocardiographic monitor and an oxygen balloon) underwent a decontamination procedure with a disinfectant. No accidents occurred during the flight. On board, the patient was receiving symptomatic treatment. The patient's condition was stable; no need arose for opening PITU en route to Moscow.

In Moscow, 2 critical care transport vehicles had been waiting for the patient. One vehicle with 2 EMS responders wearing PPE took the patient to the receiving facility. The patient was loaded into the car and taken out of the capsule. The medical crew accompanying the patient on board of the aircraft, the equipment and PITU were taken by the second vehicle to Zachshita headquarters for decontamination and cleaning. The total evacuation time was $4.5 \mathrm{~h}$; flight duration was $2 \mathrm{~h}$.

This example illustrates the protocol followed by our EMS team, which aimed at maintaining a high biosafety level during medical evacuation of patients with COVID-19 inside a PITU.

Normally, aeromedical evacuations of patients, including patients with COVID-19, are carried out in several stages. In the first stage, the EMS team prepares the patient for the flight: the patient should be stabilized, provided with oxygen or put on a ventilator if necessary. In the second stage, the patient is transported from the medical facility to the aircraft. The next stage is the flight itself. Finally, the patient is unloaded from the aircraft and taken to the receiving facility. Thus, one EMS team performs a multistage evacuation, which raises the competence bar for the team and stiffens the requirements for the equipment used during the mission.

Below, we provide another example of a multistage medical evacuation of a critically ill patient.

Patient B., 78 years, was transferred from Cherkessk to Moscow on board of a specialized aircraft; the mission was carried out by the ESM team from NCDM Zachshita. This was a 4-stage medical evacuation. Measures taken at each stage were aimed at ensuring safety at the following stage.

The first stage was preparatory. Because it was impossible to obtain exhaustive information about the patient's condition during the preceding video call and the emergency was pressing, the EMS team had to take the patient's full medical history upon arrival in Cherkessk. After the obtained data were analyzed, the patient's condition was assessed as critical. Adjustments were made to the therapy and parameters of respiratory support. After the patient was stabilized, a decision was made to transfer him to Moscow on board of a specialized aircraft.

In order to prevent the spread of COVID-19, the patient was placed in PITU. The ventilator circuit, IV lines, cables and sensors for vital signs monitoring, and drainages were passed through the service ports. All medical equipment was outside the capsule and could be accessed by the medical personnel. Before leaving the hospital, the EMS crew, PITU with the patient, and the medical equipment were decontaminated with disinfectants.

In the second stage, the patient was taken to Cherkessk airport in a class $\mathrm{C}$ critical care transport vehicle outfitted with 
monitoring and therapy equipment. Importantly, the number of maneuvers with a critically ill patient should be minimized. This means that the EMS vehicle transporting the patient should be as close as possible to the aircraft. Boarding should be performed using an ambulift, which can lift a person on a stretcher to the aircraft door. The airport in Mineralnye Vody did not have an ambulift, so the medical personnel had to load the patient in on their own, which might have had a negative effect on the patient's condition.

In the third stage, the patient was transported to Moscow on board of an An-148 aircraft outfitted with medical equipment. During the flight, the patient was on a ventilator and receiving IV therapy, his vital signs were continuously monitored. Because the aircraft was properly equipped, the EMS team were able to perform interventions safely and effectively.

In the final stage, a receiving vehicle should come as close as possible to the aircraft to pick up the patient. After the patient was loaded into a critical care transport vehicle, he was transported to the Intensive care unit of Pirogov National Medical and Surgical Center, without deterioration. PITU and the medical equipment were decontaminated. All medical materials used during the mission were single-use items and were disposed of according to the current regulations.

Although the number of COVID-19 patients is falling in Russia, CEAE and MFH medical teams still have to carry out medical evacuations.

Recently, FMBA hospitals repurposed for COVID-19 patients have started to go back to their normal routine. Executive order № 1470 of the Russian Government dated 06/03/2020 and FMBA Order № 172 dated 06/10/2020 have authorized NCDM Zachshita to perform transfers of critically ill patients from FMBA hospitals to specialized facilities. On June 16-17, EMS crews from Zashchita transported 7 patients with COVID-19 from the clinic at the Federal Center of Brain Research and Neurotechnology to specialized medical facilities for further medical care.

Below, we provide an example of a mass medical evacuation of patients with COVID-19.

Two moderately severe and 5 severe patients including one individual on mechanical ventilation were transferred from the clinic at the Federal Center of Brain Research and Neurotechnology to specialized medical facilities.

Transportation was performed by 2 critical care teams consisting of an intensivist and a paramedic and a regular EMS team consisting of a physician and a paramedic. PPE was worn by all members of the involved teams.

The first-response team (the physician and the paramedic) was tasked to assess the situation and decide on the sequence of medical evacuations [9]. Upon arrival at the clinic, the team evaluated the condition of the patients, their eligibility for transport and their need for oxygen. The team then reported to the headquarters, and the following decisions were made:

- moderately severe patients should be evacuated by the first-responders;

- another paramedic should join the critical care team because one of the patients was morbidly obese; first;

- the most severely ill patient on a vent should be evacuated

- oxygen supply should be 1.5 times higher than required for one journey to the receiving facility.

The CCT vehicle transported one patient at a time. During transport, all patients were stable. After each evacuation, the crews underwent decontamination, restocked on oxygen and proceeded to the next evacuation.
At the time of manuscript preparation, 15 mass evacuations had been carried out. The following steps should be taken to ensure successful medical evacuation of multiple patients between hospitals:

- dispatch an EMS crew to location to assess the condition of all patients eligible for transport;

- analyze the obtained data and determine the sequence of evacuations (triage);

- ensure that oxygen supply is sufficient for each journey.

Unfortunately, the number of COVID-infected patients is still high in some Russian regions. At the moment, 2 EMS teams from NCMD Zashchita are carrying out medical evacuations of patients with COVID-19 from Blagoveshchensk to the specialized facilities of Komsomolsk-on-Amur and Aldan. Between 13 and 20 of June, 2020, a total of 44 patients were transferred to the receiving facilities; the patients had confirmed or suspected COVID-19, moderately severe double pneumonia, stage I/II respiratory failure. The patients were evacuated in groups of 22 individuals. While boarding and disembarking the plane in the order or priority, a $1.5 \mathrm{~m}$ distance was kept between the patients. This distance was maintained on board; all patients were wearing face masks and medical gloves. Severely ill patients were accommodated in the forebody area to enable unobstructed access for the medical team.

An intensive care unit was deployed in Svobodny by the specialists of NCMD Zashchita to prepare severely ill patients for medical evacuation. Over 130 patients were consulted on

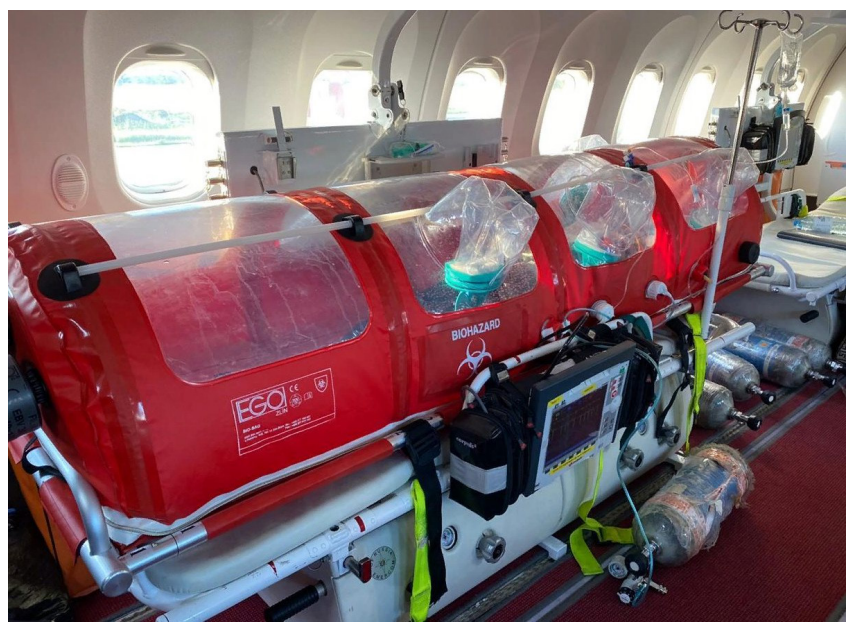

Fig. 1. Patient isolation transport unit (PITU)

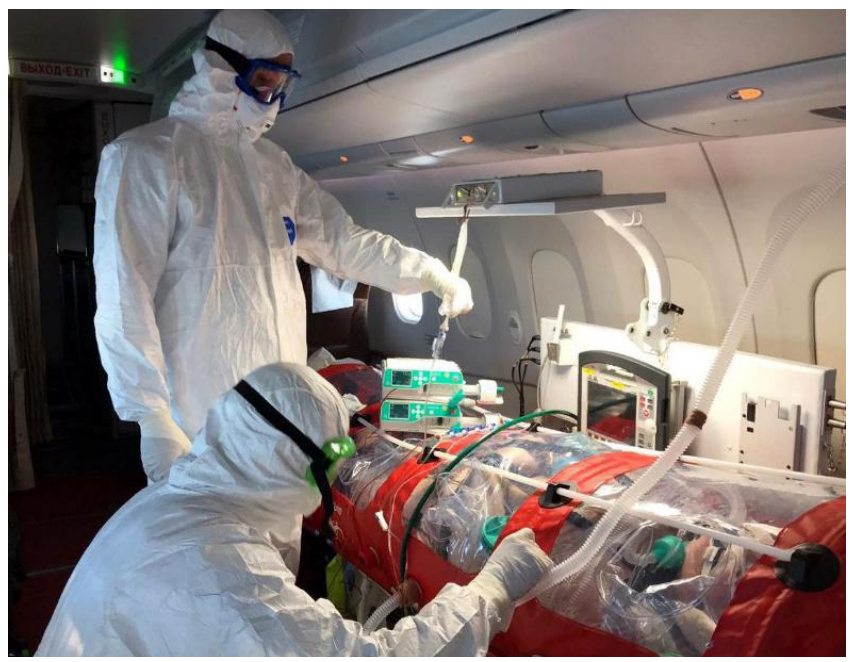

Fig. 2. Transport of patient with COVID-19 in PITU 
the possibility of medical evacuation and received supportive treatment.

Special attention was paid to the medical evacuation of the infected veterans - participants of the Victory Parade. Before the parade, about 30 veterans aged over 94 years were accommodated in a Moscow region rehab center. In case of acute respiratory or other symptoms, CEAE and MFH crews transferred the patients to the Clinical hospital № 123 for further care. On the day of the Parade, medical personnel accompanied the veterans to the Red Square and back to the facility.

FMBA will provide medical care to the participants of the Tavrida Youth Arts Forum held in Crimea in June-July 2020 In case of emergency, medical evacuations will be performed by the teams of NCMD Zashchita using the accumulated knowledge and experience.

\section{CONCLUSIONS}

1. At the beginning of the pandemic, medical evacuations of COVID-19 patients were carried out following the existing guidelines, which was sufficient to ensure biosafety of the involved EMS crews.

2. NCMD Zashchita ensures biosafety of its personnel by following the official guidelines specified in normative documents reinforced with additional techniques.

3. For long journeys over $1 \mathrm{~h}$, PPE should be donned upon arrival at the scene before leaving the EMS vehicle.

4. Prior to starting a mass medical evacuation of patients with COVID-19, their number and condition should be assessed to determine the priority sequence for evacuation and the required oxygen supply.

5. There are a few specific aspects to the aeromedical evacuation of COVID-19 patients distinguishing it from the medical evacuation of patients with other conditions. The analysis of past evacuations allowed us to significantly improve our evacuation strategies.

6. Compliance with the current guidelines and regulations at all stages of medical evacuation ensures a high level of biosafety, protects the EMS team involved, prevents the spread of infection and patient deterioration.

\section{References}

1. Metodicheskie ukazaniya MU 3.1.3260-15 "Anti-epidemic provision of the population in emergency situations, including the formation of foci of dangerous infectious diseases " (утв. Главным государственным санитарным врачом РФ 24 марта 2015 г.). Data vvedeniya 24 marta $2015 \mathrm{~g}$.

2. Prikaz Minzdravsocrazvitiya Rossii ot 31.01.2012 N 69n "About the approval of the Order of rendering medical care to adult patients with infectious diseases".

3. Vremennye metodicheskie rekomendacii «Prevention, diagnosis and treat ment of new coronavirus infection (COVID-19)» versiya 7 ot $28.04 .2020 \mathrm{~g}$

4. Prikaz Federal'nogo mediko-biologicheskogo agentstva ot 18 aprelya 2020 g. № 112 " About prevention of nosocomial infection of the personnel of medical organizations of FMBA of Russia with a new coronavirus infection COVID-19".

5. Prikaz Federal'nogo mediko-biologicheskogo agentstva ot 24

\section{Литература}

1. Методические указания МУ 3.1.3260-15 "Противоэпидемическое обеспечение населения в условиях чрезвычайных ситуаций, в том числе при формировании очагов опасных инфекционных заболеваний" (утв. Главным государственным санитарным врачом РФ 24 марта 2015 г.). Дата введения 24 марта 2015 г.

2. Приказ Министерства здравоохранения и социального развития РФ от 31.01.2012 г. N 69н "Об утверждении Порядка оказания медицинской помощи взрослым больным при инфекционных заболеваниях".

3. Временные методические рекомендации «Профилактика диагностика и лечение новой коронавирусной инфекции (COVID-19)» версия 7 (утв. Заместителем Министра здравоохранения Российской Федерации Е.Г. Камкиным) от 03.06.2020 г

4. Приказ Федерального медико-биологического агентства от 18 апреля 2020 г. N 112 "О профилактике внутрибольничного инсрицирования персонала медицинских организаций ФМБА России новой коронавирусной инфекцией COVID-19".

5. Приказ Федерального медико-биологического агентства от 24 апреля 2020 г. N 126 "О внесении изменений в приказ ФМБА России от 18 апреля 2020 г. N 112 "О профилактике внутрибольничного инсицирования персонала медицинских организаций ФМБА России новой коронавирусной инфекцией

\section{COVID-19"}

6. Проект методических рекомендаций «Медицинская эвакуация пациентов с инфекционными заболеваниями, в том числе больных или лиц с подозрением на болезнь, вызванную возбудителями особо опасных инфекций». М.: ВЦМК «Защита». 39 c. http://www.vcmk.ru/metod rek/proekt/ Проект_27.01.20.pdf. Дата обращения 22.06.2020 г.

7. Баранова Н.Н. Акиньшин А.В., Немаев С.А. Мешков М.А., Зеленцов К.М., Письменный В.П. Организация медицинской эвакуации пациентов с подозрением на новую коронавирусную инфекцию COVID-19. // Медицина катастроф. 2020, №1. С. 67-70.

8. Гончаров С.Ф., Соколов М.Э., Баранова Н.Н., Солодова Р.Ф. Концепция переносного изолируемого роботизированного медицинского модуля для эвакуации больных и пострадавших // Медико-биологические и социально-психологические проблемы безопасности в чрезвычайных ситуациях. 2020 № 3, C. 24-32.

9. Постановление Главного государственного санитарного врача Российской Федерации от 9 декабря 2010 г. N 163 "Об утверждении СанПиН 2.1.7.2790-10 "Санитарноэпидемиологические требования К обращению с медицинскими отходами". 